\title{
Aerobic Denitrifiers: Characteristics and Recent Research
}

\author{
Huiying $\mathrm{Li}^{1, \mathrm{a}}$, Wenxiang Wang ${ }^{1, \mathrm{~b}}$, Shaobin Huang ${ }^{2, \mathrm{c}}$
}

${ }^{1}$ Deparment of heavy metal pollution control and comprehensive utilization of resources key laboratory, Guangdong Polytechnic of Environmental Protection Engineering, Foshan,528216,Chnia

${ }^{2}$ College of Environmental Science and Engineering, South China University of Technology

University City, Guangzhou ,510006, China

aemail: 125390881@qq.com, bemail: 66450477@qq.com, cemail:chshuang@ scut. edu.cn

Keywords: Aerobic denitrification; Aerobic denitrifiers; Effect mechanism

\begin{abstract}
The presence of nitrogenous substances in wastewater discharges has attracted attention because of the role of nitrogen in eutrophication of receiving waters. Nitrogen removal is an important aspect of present day wastewater treatment processes. However, conventional nitrification-denitrification treatment is uneconomical and difficult to operate due to extremely slow nitrification and the necessity for separate nitrification and denitrification reactors. Recently, several novel aerobic denitrification processes have been developed for cost-effective biological nitrogen removal. These processes can reduce inorganic nitrate compounds to harmless nitrogen gas. Aerobic denitrification bacteria screened and identified in recent years and the nitrogen removal effects of those bacteria are summarized.
\end{abstract}

\section{Introduction}

Attention to nitrogen pollution treatment is growing. Nitrogenous compounds are major water pollutants originating from domestic, agricultural, and aqueous industrial waste, which can create serious problems when released into the environment, such as eutrophication of rivers ${ }^{[1]}$, deterioration of water quality and potential hazards to human and animal health. Contamination of groundwater by nitrate is primarily attributed to non-point agricultural sources ${ }^{[2]}$. Due to increased use of fertilizers, runoff of nitrate from agriculture is increasing all over the world. Other sources of nitrate in ground and surface water are from uncontrolled land discharges of treated or raw wastewater from domestic and industrial wastes, landfills ${ }^{[3]}$ and animal wastes, particularly from animal farms ${ }^{[4]}$. The concentration of nitrogen compounds in some industrial wastewaters is much higher than in groundwater and surface water. Some industrial wastewaters are reported to contain more than $200 \mathrm{mg} \mathrm{NO}{ }_{3}^{-}-\mathrm{N} / \mathrm{L}^{[5-7]}$. For example, the effluent from the production of explosives, fertilizer $^{[8]}$, pectin, cellophane, and metals finishing industries contain more than $1000 \mathrm{mg}$ $\mathrm{NO}_{3}{ }^{-}-\mathrm{N} / \mathrm{L}^{[9]}$. Furthermore, the nuclear industry produces nitrate-loaded wastes at very high concentrations at many points during the nuclear fuel cycle. It is reported that the processing of radioactive metal products at nuclear weapons production plants and research labs products wastewater containing more than 50,000 $\mathrm{mg} \mathrm{NO}_{3}{ }^{-}-\mathrm{N} / \mathrm{L}$, primarily derived from nitric acid used for metal cleaning ${ }^{[10]}$. Thus, methods of remediation of nitrate-polluted aquifers are of considerable interest.

Ion exchange (IE), reverse osmosis (RO) and electrodialysis (ED) are the most common physicochemical processes reported for the removal of nitrate ${ }^{[11]}$. However, the utility of these processes has been limited due to the build-up of byproducts, non-selectivity for target contaminants and high treatment cost. Conventional biological nitrogen removal systems based on the principle that nitrification $\left(\mathrm{NH}_{4} \rightarrow \mathrm{NH}_{2} \mathrm{OH} \rightarrow \mathrm{NO}_{2}{ }^{-} \rightarrow \mathrm{NO}_{3}{ }^{-}\right)$is an aerobic process by autotrophs, such as Nitrosomonas spp. and Nitrobacter spp., and denitrification $\left(\mathrm{NO}_{3}{ }^{-}\right.$ $\rightarrow \mathrm{NO}_{2}{ }^{-} \rightarrow \mathrm{NO} \rightarrow \mathrm{N}_{2} \mathrm{O} \rightarrow \mathrm{N}_{2}$ ) by heterotrophs, is restricted to anoxic conditions ${ }^{[12,13]}$, which implies spatial separation of nitrifying and denitrifying units, or temporal separation of each step by 
alternating aeration and no aeration in the same unit and can be uneconomical. Furthermore, for high ammonia/low carbon leachate, the method of biological nitrogen removal usually needs air-stripping pretreatment and external carbon sources, such as methanol, to optimize the $\mathrm{C} / \mathrm{N}$ ratio ${ }^{[14,15]}$, so it proceeds slowly due to low microbial activity and yield and it is generally performed only for wastewaters containing low concentrations of nitrogen ${ }^{[13]}$. However, some researchers(Robertson et al. 1988) have found that denitrification can occur under aerobic conditions. Aerobic denitrification, as a way to remove nitrogen from wastewater, makes it possible for denitrification and nitrification to occur simultaneously in a single reactor, which greatly reduces operation cost and other problems ${ }^{[16]}$. Nitrogen removal efficiency can be improved markedly by using aerobic denitrifiers. Thus, many researchers are interested in the phenomenon of aerobic denitrification. Various aerobic denitrifiers have been isolated and identified. Research into the mechanism and applications has also progressed.

\section{Aerobic Denitrifiers}

Research on aerobic denitrifiers began in the 1980s. Robertson et al. ${ }^{[17]}$ isolated aerobic denitrifiers, i.e., Paracoccus pantotropha, Pseudomonas sp. and Alcaligenes faecalis, from the effluent of a sulfur removal and denitrification treatment system. These had an aerobic denitrification rate (at around $5.6 \mathrm{mg} / \mathrm{L}$ of dissolved oxygen) equivalent to $50 \%$ of that calculated under anoxic conditions ${ }^{[17]}$ and were also capable of heterotrophic nitrification ${ }^{[18]}$. Later, some

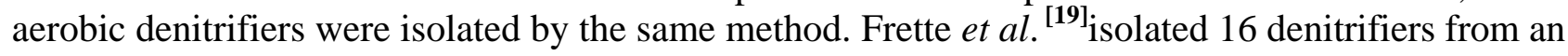
intermittent anaerobic/aerobic wastewater treatment tank that denitrified under either aerobic or anaerobic condition. After $40 \mathrm{~h}$ incubation, $90.8 \%$ of the total nitrogen was removed and the cell yield increased five-fold. They found that the optimum denitrification activity was obtained when the substrates total $\mathrm{C} / \mathrm{N}$ ratio was between 4 and 5 and the dissolved oxygen concentration was between 2 and $6 \mathrm{mg} / \mathrm{L}$. Frette et al. ${ }^{[20]}$ isolated 16 denitrifiers from an intermittent anaerobic/aerobic wastewater treatment tank that denitrified under either aerobic or anaerobic condition. Pai et al. ${ }^{[21]}$ isolated three aerobic denitrifiers from corn sediment, one of which, the T6 germ, can grow utilizing inorganic nitrogen, i.e., $\mathrm{NH}^{4+}-\mathrm{N}$ andNO${ }_{2}-\mathrm{N}$, or even with organic nitrogen. Recently, some other bacteria have shown aerobic denitrification capability, such as Hyphomicrobium $X^{[22]}$, Klebsiella $^{[23]}$, Ochrobactrum ${ }^{[24]}$ and Zoogloea ${ }^{[21]}$. By adopting two sequencing batch reactors (SBRs), nitrate as the substrate, and an intermittent aeration mode, activated sludge was domesticated to enrich aerobic denitrifiers. Under optimal conditions, Wang et al. ${ }^{[16]}$ isolated 20 bacteria from the two SBRs, and 8 bacteria werefound to belong to the genera Pseu domonas, Delftia, Herbaspirillum and Comamonas. Pseudomonas and Delftia were primarily in one reactor and Herbaspirillum and Comamonas colonized the other. The bacteria isolated exhibited a strong nitrate reducing capability with a high gas yield but a low nitrite yield. The discovery of these aerobic denitrifiers further demonstrates their ubiquitous existence and promotes interest in studies of their denitrifying mechanism under aerobic conditions. 
Table 1.-Aerobic denitrifiers and their sources

\begin{tabular}{|c|c|c|c|c|c|}
\hline Denitrifiers & Stains & DO & $\begin{array}{l}\text { Nitrogen removal } \\
\text { rate }\end{array}$ & Source & Reference \\
\hline \multirow[t]{3}{*}{ Paracoccus } & P.denitrification & $2.25 \mathrm{mg} / \mathrm{L}$ & $1.380 \mathrm{mmol} /(\mathrm{g} \cdot \mathrm{h})$ & Desulphurisation and & [25] \\
\hline & DSM2944 & & & denitrification systems & [26] \\
\hline & P.sp.DB2 & $7.50 \mathrm{mg} / \mathrm{L}$ & $0.128 \mathrm{mmol} /(\mathrm{g} \cdot \mathrm{h})$ & wastewater & \\
\hline \multirow[t]{7}{*}{ Pseudomonas } & P.sp.strain K50 & $38 \mu \mathrm{mol} / \mathrm{L}$ & $0.03 \mu \mathrm{mol} / \mathrm{min}$ & Activated sludge & {$[27]$} \\
\hline & P.stutzri TR2 & $39 \mu \mathrm{mol} / \mathrm{L}$ & $0.9 \mu \mathrm{mol} / \mathrm{min}$ & Activated sludge & {$[27]$} \\
\hline & $\begin{array}{l}\text { P.aeruginasa ATCC } \\
9027\end{array}$ & $1.0-1.3 \mathrm{mg} / \mathrm{L}$ & $0.215 \mathrm{mmol} /(\mathrm{g} \cdot \mathrm{h})$ & $\begin{array}{l}\text { Oil-contaminated soil, } \\
\text { groundwater }\end{array}$ & {$[28]$} \\
\hline & P.butamovora & $1.85-2.45 \mathrm{mg} / \mathrm{L}$ & $2.60 \mathrm{mmol} /(\mathrm{L} \cdot \mathrm{h})$ & $\begin{array}{l}\text { The soil of highly } \\
\text { contaminated land }\end{array}$ & [29] \\
\hline & P.stutzri $\mathrm{SU}_{2}$ & 92\%(Gases) & $\begin{array}{l}0.032 \mathrm{mmolN} / \mathrm{g}(\mathrm{dry} \\
\text { weight }) \cdot \mathrm{h}\end{array}$ & $\begin{array}{l}\text { Pigsties wastewater } \\
\text { treatment system }\end{array}$ & {$[30]$} \\
\hline & P.stutzri HS-03 & $5.0-6.0 \mathrm{mg} / \mathrm{L}$ & & Activated sludge & {$[31]$} \\
\hline & P.putida AD-21 & & $254.6 \mathrm{mg} / \mathrm{L} \cdot \mathrm{h}$ & Soil & \\
\hline \multirow[t]{4}{*}{ Alcaligenes } & A.faecalis & & $28.9 \mathrm{mg} /(\mathrm{L} \cdot \mathrm{h})$ & $\begin{array}{l}\text { Desulphurisation and } \\
\text { denitrification systems }\end{array}$ & {$[25]$} \\
\hline & C.tesosteroni DB9 & $7.50 \mathrm{mg} / \mathrm{L}$ & $0.06 \mathrm{mmol} /(\mathrm{L} \cdot \mathrm{h})$ & Diverse natural and & {$[26]$} \\
\hline & C.tesosteroni DR7 & $7.50 \mathrm{mg} / \mathrm{L}$ & $0.179 \mathrm{mmol} /(\mathrm{g} \cdot \mathrm{h})$ & managed ecosystems & {$[26]$} \\
\hline & $\begin{array}{l}\text { Alcaligenes faecalis } \\
\text { NO. } 4\end{array}$ & & & Sewage sludge & {$[13]$} \\
\hline Citrobacter & C. diversus & 3.1-3.8 mg/L & $90.8 \%$ & Sludge & [19] \\
\hline Rhodococcus & R. sp. HN & & & Soil & {$[32]$} \\
\hline \multirow[t]{4}{*}{ Bacillus } & Bacillus cereus & 30\%(Gases) & 78-94\% & Night soil & [33] \\
\hline & Bacillus & & & & \\
\hline & licheniformis & 30\%(Gases) & 78-94\% & Night soil & {$[33]$} \\
\hline & Bacillus subtilis & 30\%(Gases) & $78-94 \%$ & Night soil & [33] \\
\hline Zoogloea & Z.strain TL1 & $0.75 \mathrm{mg} / \mathrm{L}$ & $0.096 \mathrm{mmolN} / \mathrm{L} \cdot \mathrm{h}$ & Activated sludge & [34] \\
\hline
\end{tabular}

\section{Mechanism of Aerobic Denitrification}

\subsection{Co-respiration theory}

The criteria that must be satisfied to establish that a bacterium is an aerobic denitrifier are that it must be able to express the proteins and enzymes involved in denitrification under oxic growth conditions, and the reactions of denitrification themselves must occur when the bacteria are under oxic conditions. The criteria have been shown to be satisfied by T. pantotropha ${ }^{[35,36]}$, but the aerobic expression of the denitrification enzymes has not been studied in detail. The aerobic denitrification mechanism of $T$. pantotropha was established by Robertson et $a l^{[17]}$., who showed that co-respiration is an important mechanism in aerobic denitrification. Co-respiration means that oxygen and nitrate are simultaneously used as electron acceptors. The occurrence of simultaneous electron flow to oxygen and nitrogenous oxides has been explained by the hypothesis that, in this organism, there is a 'bottleneck' in its respiratory chain to oxygen ${ }^{[37]}$. Robertson and Kuenen ${ }^{[38]}$ found that after switching growth conditions from oxic to anoxic, there is no lag before growth of $T$. pantotropha, indicating that the denitrification pathway is expressed constitutively. This property appears to confer a selective advantage to $T$. pantotropha over Paracoccus denitrificans (which has been considered for many years to denitrify only anaerobically) under conditions fluctuating between oxic and anoxic.

\subsection{Denitrification enzymes}

Since molecular oxygen has been shown to repress denitrification enzymes, the mechanism of aerobic denitrification has received considerable attention. Ample literature has been published on the peculiar enzyme system to explain its properties in aerobic denitrification. Denitrification is a very complex process and it may be estimated that at least 40 genes are involved to form the structural proteins and their prosthetic groups and cofactors, the components of specific transport 
mechanisms for uptake of metals (molybdenum and copper) and regulatory proteins. It is clear now that four reductases are involved in denitrification: nitrate reductase, nitrite reductase, nitric oxide reductase and nitrous oxide reductase.

Two nitrate reductases (NAR) were present in T. pantotropha ${ }^{[39]}$. Fractionation of cells grown aerobically or anaerobically in the presence of nitrate revealed an anaerobically active membrane bound NAR and an aerobically active periplasmic NAR. The catalytic properties of the two NARs were clearly distinct. The periplasmic NAR was not able to use chlorate as an alternative electron acceptor and was not sensitive to azide. Only the membrane bound NAR could be coupled to NADH dehydrogenase. Bell et al. ${ }^{[37]}$ put growing T. pantotropha under anaerobic and aerobic conditions and measured the capacity for nitrate reduction of each type of intact cell, using succinate as the electron donor. The membrane-bound and periplasmic nitrate reductases were investigated. The results confirm that: (i) the membrane-bound NAR is predominantly expressed during growth under anaerobic denitrifying conditions and is only operative under anaerobic conditions; (ii) the periplasmic NAR is predominantly expressed when cells are grown in an aerobic denitrifying manner and can operate under both anaerobic and aerobic conditions; (iii) the periplasmic enzyme is present in anaerobically grown cells and accounts for their capacity for aerobic nitrate reduction. The periplasmic NAR is more highly expressed aerobically than anaerobically in T. pantotropha, whereas the reverse is true for the membrane-bound NAR (Bell et al. ${ }^{[40]}$ ).

Richardson and Ferguson ${ }^{[41]}$ found that aerobic expression of the periplasmic NAR by $T$. pantotropha was not dependent on the presence or absence of nitrate, but its expression was largely influenced by the kind of carbon source used. The more reduced the C-source (butyrate or caproate) the higher the periplasmic NAR activity, confirming its possible function as a redox valve during aerobic growth. The periplasmic NAR from T. pantotropha was isolated by Berks et al. ${ }^{[42,43]}$ and the genes encoding the enzyme (napEDABC) were characterized. The expression of two distinct nitrate reductase activities raises questions as to the mechanism of their different regulation. To further investigate, mutants defective in membrane-bound NAR were generated by Tn5 insertion in the NAR gene ${ }^{[40]}$. One such mutant, M-6, was deficient in membrane-bound NAR activity but retained a periplasmic NAR activity. Under anaerobic growth conditions, M-6 over-expressed the periplasmic nitrate reductase activity. Berks et al.(1995) inferred a regulation link between the two reductase activities. This was the first demonstration of full denitrification in an organism possessing only a periplasmic nitrate reductase. Localization studies showed also that, in M-6, $100 \%$ of the NAR could be recovered from the periplasm. The lower growth rates and yields of mutant M-6 are plausibly a consequence of reduced energy conservation by the periplasmic NAR, compared with the membrane bound NAR in the span from ubiquinol to nitrate. Such difference in energetic coupling is in accord with current ideas about electron transport mediated phosphorylation during denitrification ${ }^{[44]}$.

Current research on nitrite reductase of $T$. pantotropha is controversial. Nitrite reductases involved in denitrification have been purified from several bacteria and appear to be of two types: a heme cd1-containing enzyme and a copper-containing enzyme. The first type contains two types of prosthetic groups: heme $\mathrm{c}$, which is covalently linked to the protein, and a non-covalently bound heme $\mathrm{d}$. Therefore this type of nitrite reductase, which is also found in P. denitrificans, is often referred to as cytochrome cd1. Their presence is mutually exclusive for reasons not known. The two enzymes are functionally and physiologically equivalent, as indicated by the finding that the copper-containing nitrite reductase from Pseudomonas aureofaciens can be cloned in an active form in Pseudomonas stutzeri in which the gene encoding the heme-containing enzyme had been disrupted ${ }^{[45]}$. Stouthamer ${ }^{[46]}$ found that the nitrite reductase of $T$. pantotropha is the copper-containing nitrite reductase, which is still active under aerobic conditions. Paitian et al. ${ }^{[47]}$ found that nitrite reduction by the alternative nitrite reductase, cytochrome cd1, is strongly inhibited by oxygen and denitrification at high concentrations of dissolved oxygen may not be possible for bacteria dependent on this enzyme. As cytochrome cd1 can also serve as a terminal oxidase, it has been suggested that the inhibition of nitrite reduction by this cytochrome might be 
due to its reaction with oxygen ${ }^{[48]}$. Similar behavior for the copper nitrite reductase has not been reported. Moir et al. ${ }^{[49]}$ found the same type of nitrite reductase of $T$ pantotropha in aerobic or anaerobic conditions, and identified it as belonging to cytochrome cd1. The formation of the enzymes involved in denitrification was studied in chemostat cultures of $T$. pantotropha at various oxygen tensions ${ }^{[50]}$. It was found that cytochrome cd1 nitrite reductase was severely repressed in the presence of oxygen.

At present, the two different points of view have not been unified, there have been few recent studies of nitric oxide and nitrous oxide enzymes. All the research of which we are aware indicates that both enzymes are active under aerobic conditions ${ }^{[38]}$.

\section{Prospects}

Aerobic denitrification has significant applications in wastewater treatment as well as in biological NOX treatment. It also has applications in the development of novel techniques for nitrate removal. However, research is still necessary in this area, as follows: (1) the aerobic denitrifiers isolated to date only present denitrifying activity at low DO concentrations, so we should seek high activity bacteria with denitrifying capacity under severe conditions, such as high temperature or high $\mathrm{pH}$; (2) it's necessary to quantify the possible unwanted emissions of nitric or nitrous oxides by incomplete aerobic denitrification. To prevent such problems, it is first essential to obtain regulation of the enzymes and the implied environmental factors affecting their function. It has also become evident that the combined efforts of microbiologists, chemists and engineers are necessary to ensure that the contributions from microbiology and molecular biology can be incorporated into the design, operation and control of bioreactors and wastewater treatment systems. This is the biggest challenge facing environmental microbiology.

\section{Acknowledgment}

Research Project of Guangdong Provincial Department of Science and Technology (Grants No. 2016B020240002 and 2015B020236001). Research Project of Guangdong Provincial Department of Science and Technology (Grants No. 2016B020240002).Special fund of environmental protection in Guangdong Province in 2015 ([2015]318); Provincial financial technology research and Development Grant Program in 2015([2015]639); Foshan science and technology project in 2015(2015AB004322).

\section{References}

[1] Sumino T, Isaka K, Ikuta $\mathrm{H}$, et al. Nitrogen removal from wastewater using simultaneous nitrate reduction and anaerobic ammonium oxidation in single reactor. J Biosci Bioeng, 2006, 102 (4):346-351.

[2] Feleke Z, Sakakibara Y A. Bio-electrochemical reactor coupled with adsorber for the removal of nitrate and inhibitory pesticide. Water Res, 2002, 36: 3092-3102.

[3] Islam S, Suidan M T. Electrolytic denitrification: long term performance and effect of current intensity. Water Res, 1998, 32(2): 528-536.

[4] Terada A, Hibiya K, Nagai J, et al. Nitrogen removal characteristics and biofilm analysis of a membrane-aerated biofilm reactor applicable to high-strength nitrogenous wastewater treatment. $\mathrm{J}$ Biosci Bioeng, 2003, 95 (2): 170-178.

[5] Almeida J S, Reis M A M, Carrondo M J T. Competition between nitrate and nitrite reduction in denitrification by Pseudomonas fluorescens. Biotechnol Bioeng, 1995,46: 476-484.

[6] Zayed G, Winter J. Removal of organic pollutants and of nitrate from wastewater from dairy industry by denitrification. Appl Microbiol Biotechnol, 1998, 49: 469-474. 
[7] Peyton B M, Mormile M R, Petersen J N. Nitrate reduction with Halomonas Campisalis: kinetics of denitrification at pH9 and 12.5\% NaCl. Water Res, 2001, 35: 4237-4242.

[8] Watanabe T, Motoyama H, Kuroda M. Denitrification and neutralization treatment by direct feeding of an acidic wastewater containing copper ion and high-strength nitrate to a bio-electrochemical reactor process. Water Res, 2001, 35 (17): 4102-4110.

[9] Glass C, Silverstein J. Denitrification of high-nitrate, high-salinity wastewater. Water Res, 1999, 33 (1): 223-229.

[10] Francis C W, Hatcher C W. Biological denitrification of high nitrate wastes generated in the nuclear industry. In: Cooper, P F, Atkinson, B (Eds.), Biological Fluidized Bed Treatment of Water and Wastewater. Ellis Horwood Ltd., Chichester, 1980.

[11] Dhab F. Treatment alternatives for nitrate contaminated groundwater supplies. Environ Syst , 1987, 17: 65-75.

[12] Tchobanoglous G. and Burton F L. Wastewater engineering: treatment, disposal and reuse,1991, 429-433.

[13] Joo H S, Hirai M and Shoda, M. Characteristics of ammonium removal by heterotrophic nitrification-aerobic denitrification by Alcaligenes faecalis no. 4. J Biosci Bioeng, 2005, 100: 184-191.

[14] Lu P, Ceng L X, Zhang Q Y, et al. Study on the methods for the treatment of high ammonia concentration leachate. China Water Wastewater(in Chinese with English abstract), 2003, 19: 44-45.

[15] Carley B N and Mavinic D C. The effects of external carbon loading on nitrification and denitrification of a high ammonia landfill leachate. Water Environ Res, 1991, 63: 51-59.

[16] Wang P, Li X T, Xiang M F, et al. Characterization of efficient aerobic denitrifiers isolated from two different sequencing batch reactors by 16S-rRNA analysis. J Biosci Bioeng, 2007, 103(6): 563-567.

[17] Robertson L A , Neil E W J and Torremans R A M, et al. Simultaneous nitrification and denitrification in aerobic chemostat cultures of Thiosphaera pantotropha. Appl Environ Microbiol, 1988, 54, 2812-2818.

[18] Robertson L A , Cornelisse R , De Vos P, et al. Aerobic denitrification in various heterotrophic nitrifiers. Antonie van Leeuwenhoek, 1989, 56: 289-299.

[19] Huang $\mathrm{H}$ K and Tseng S K. Nitrate reduction by Citrobacter diversus under aerobic environment. Appl Microbiol Biotechnol, 2001, 55: 90-94.

[20] Frette L, Gejlsbjerg B and Westermann P. Aerobic denitrifiers isolated from an alternating activated sludge system. FEMS Microbiol Ecol, 1997, 24: 363-3701.

[21] Pai S L, Chong N M and Chen C H. Potential applications of aerobic denitrifying bacteria as bioagents in wastewater treatment. Bioresour Technol, 1999, 68: 179-185.

[22] Meiberg J B M, Bruinenbrg P M, and Harder W. Effect of dissolved oxygen tension on the metabolism of methylated amines in Hyphomicrobium Xin the absence and presence of nitrate: aerobic denitrification. Gen Microbiol, 1980, 120: 453-463.

[23] Takaya N, Catalan-Sakairi M A B, Sakaguchi Y, et al. Aerobic denitrification bacteria that produce low levels of nitrousoxide. Appl Environ Microbiol, 2003, 69: 3152-3157.

[24] Lukow T and Diekmann H. Aerobic denitrification by a newly isolated heterotrophic bacterium strain TL1. Biotechnol Lett,1997, 19: 1157-1159. 
[25] Robertson L A, Kuenen J G. 1989. Thiospaera pantotropha gen. nov. sp. nov., a facultatively anaerobic, facultatively autotrophic sulphur bacterium. Journal of General Microbiology, 129(8): 2847-2855.

[26] Patureau D, Zumstein E, Delgenes J P, et a1. Aerobic denitrifiers isolated from diverse natural and managed ecosystems.Microbial Ecology, 2000, 39: 145-152.

[27] Naoki T, Maria A B, Yasushi S, et a1. Aerobic denitrifying bacteria that produce low levels of nitrous oxide. Applied and Environmental Microbiology, 2003, 69(6): 3152-3157.

[28] Ridgway H F, Safarik J, Phipps D, et a1. Identification and catabolic activity of well-derived gasoline degrading bacteria from a contaminated aquifer. Applied and Environmental Microbiology, 1990, 56: 3565-3575.

[29] Kesserú P, Kiss I, Bihari Z, et al. Biological denitrification in a continuous-flow pilot bioreactor containing immobilized Pseudomonas butannovora cells. Bioresource Technology, 2003, 87: 75-80.

[30] Su J J, Liu B Y, Lin J, et al. Isolation of an aerobic denitrifying bacterial strain NS-2 from the activated sludge of piggery wastewater treatment systems in Taiwan possessing denitrification under 92\% oxygen atmosphere. Journal of Applied Microbiology. 2001, 91(5): 853-860.

[31] Mia K, Sun J C, Su J Y, et al. Aerobic denitrification of Pseudomonas putida AD-21. J Biosci Bioeng, 2008, 106(5):498-502.

[32] Zhang G Y, Chen P Q. Isolation, identification and characteristics of aerobic denitrifying bacteria. Journal of Microbiology(in Chinese with English abstract), 2005, 2 (6): 23-25.

[33] Joong K K, Kyoung J P, Kyoung S C, et a1. Aerobic nitrification-denitrification by heterotrophic Bacillus strains. Bioresource Technology,2005, 96: 1897-1906.

[34] Lukow T, Diekmann H. Aerobic denitrification by a newly isolated heterotrophic bacterium strain TL1. Biotechnology Letters, 1997, 11(19): 1157-1159.

[35] Bell L C, Richardson D J, Ferguson S J. Periplasmic and membrane-bound respiratory nitrate reductases in Thiosphaera pantotropha: the periplasmic enzyme catalyses the first step of aerobic denitrification. FEBS Lett, 1990, 265:85-87.

[36] Bell L C, Ferguson S J. Nitric and nitrous oxide reductases are active under aerobic conditions in cells of Thiosphaera pantotropha. Biochem J, 1991, 273: 423-427.

[37] Robertson L A, Kuenen, J G. Combined heterotrophic nitrification and denitrification in Thiosphaera pantotropha and other bacteria. Antonie Van Leeuwenhoek, 1990, 57:139-152.

[38] Robertson L A, Kuenen J G. Aerobic denitrification: a controversy revived. Arch Microbiol, 1984,139: 351-354.

[39] Robertson L A, Kuenen J G. Heterotrophic nitrification in Thiosphaera pantotropha: Oxygen uptake and enzyme studies. J Gen, Microbiol. 1988, 134: 857-863.

[40] Bell L C, Page M D, Berks B C, et al. Insertion of transposon Tn5 into a structural gene of the membrane-bound nitrate reductase of Thiosphaera pantotropha results in anaerobic expression of periplasmic nitrate reductase activity. J Gen Microbiol,

1993, 139: 3205-3214.

[41] Richardson D J, Ferguson S J. The influence of carbon substrate on the activity of the periplasmic nitrate reductase in aerobically grown Thiosphaera pantothropa. Arch Microbiol, 1992, 157: 535-537. 
[42] Berks B C, Richardson D J, Robinson C, et al. Purification and characterization of the periplasmic nitrate reductase from Thiosphaera pantotropha. Eur J Biochem, 1994, 220: 117-124.

[43] Berks B C, Richardson D J, Reilly A, et al. The napEDABC gene cluster encoding the periplasmic nitrate reductase system of Thiosphaera pantotropha. Biochem J, 1995, 309: 983-992.

[44] Ferguson S J. Denitrification and its control. A van Leeuwenhoek, 1994, 66: 89-110.

[45] Glockner A B, Jungst A, Zumft W G.. Copper-containing nitrite reductase from Pseudomonas aureofaciens is functional in a mutationally cytochrome cd1-free background (NirS-) of Pseudomonas stutzeri. Arch Microbiol, 1993, 160: 18-26.

[46] Stouthamer A H. Metabolic pathways in Paracoccus denitrification and closely related bacteria in relation to the phylogeny of prokaryotes. Antonie van Leeuwenhoek, 1992, 61(1): 11-33.

[47] Paitian N A, Markossian K A, Nalbandyan R M. Biochem. Biophys Res Com, 1985, 133:1104-1111.

[48] Kučera I, Laucik J, Dadák V. The function of cytoplasmic membrane of Paracoccus denitrificans in controlling the rate of terminal acceptors. Eur J Biochem, 1983, 136: 135-140.

[49] Moir J WB, Baratta D, Richardson D J, et al. The purification of a cd1-type nitrite reductase from and the absence of acopper- type nitrite reductase from the aerobic denitrifier Thiosphaera pantotropha: the role of pseudoazurin as an electron donor. Eur J Biochem, 1993, 212: 377-385.

[50] Moir J W B, Richardson D J, Ferguson S J. The expression of redox proteins of denitrification in Thiosphaera pantotropha grown with oxygen, nitrate, and nitrous oxide as electron acceptors. Arch Microbiol, 1995, 164: 43-49. 